\title{
The Credibility of Monetary Policy and Procyclical Fiscal Policy
}

\author{
Syahid Izzulhaq ${ }^{1} \&$ Akhmad Syakir Kurnia ${ }^{1}$ \\ ${ }^{1}$ Department of Economics, Faculty of Economics and Business, Diponegoro University, Semarang, Indonesia \\ Correspondence: Syahid Izzulhaq, Building C, FEB Tembalang Campus, The Faculty of Economics and Business, \\ Diponegoro University, H. Prof. Soedarto SH. Street, 50275 Tembalang, Semarang, Indonesia.
}

Received: December 27, 2021

Accepted: February 8, $2022 \quad$ Available online: February 14, 2022

doi:10.11114/aef.v9i1.5482

URL: https://doi.org/10.11114/aef.v9i1.5482

\begin{abstract}
If indiscipline fiscal policy could affect the monetary policy's objective and effectiveness, is it necessarily mean that the status quo of monetary policy credibility would also be impacted? This paper addresses the issue by constructing a simple theoretical model and conducting empirical investigations using a dataset from 25 selected Inflation Targeting Framework countries throughout 2003-2017. By employing the Generalized Method of Moments, we find that the monetary policy will remain the status quo credible as the central bank would optimally respond to the disturbances originated from procyclical fiscal policy. However, such a response potentially crowds out domestic investment and slows down the economy, and induces financial instability. This implies that bearing the eye only on the status quo credibility of monetary policy is not sufficient, and the consideration over the fiscal policy behavior becomes crucial.
\end{abstract}

Keywords: credibility of monetary policy, procyclical fiscal policy, inflation rate

JEL Classification: E52, E58, E63

\section{Introduction}

The credibility of monetary policy is a critical element for the central banks, especially in the current era of the Inflation Targeting Framework (ITF) (Warjiyo and Juhro 2019). Kydland and Prescott (1977) revealed that through time consistent (or credible) economic policy, or particularly, in monetary policy, the central bank could attain both the optimal policy objectives and outcomes. Fellner (1979) also explained that the so-called credibility hypothesis, the foregone output costs of a disinflationary episode, will be minor if the public correctly believes that the attempt will not be abandoned. Blinder (2000) found that most central bankers believe that greater credibility makes disinflation less costly and helps hold down inflation once it is low, making it easier to defend the currency when necessary. Moreira (2012) showed that credible monetary policy generates a more stable economy, which prevents an adverse effect of interest rate shocks on macroeconomic stability. Kabundi and Mlachila (2019) also demonstrated that the credibility of monetary policy has an essential role in reducing exchange rate pass-through in South Africa. Adler, Lama, and Medina (2019) showed that monetary policy credibility ensures the effectiveness of sterilized foreign exchange intervention to maintain a stable exchange rate and inflation rate.

Voluminous works of classic literature have also extensively examined the determinants of monetary policy credibility. Barro and Gordon (1983) demonstrated that reputational aspects of the monetary authority help the monetary policy pursue and sustain its credibility. Mccallum (1984) examined the critical role of the monetary policy rule by revisiting Kydland and Prescott (1977) and Fellner (1979) hypotheses. He confirmed that the time-consistency of monetary policy, which is reflected by its policy rule, enhances the credibility of monetary policy by forming the public expectation of inflation, which in turn generates a lower inflation rate with a lower cost on unemployment. Several works of literature also emphasized that the less central bank independence from the government and political decision-making restrain the credibility of monetary policy, which deteriorates price level stability (e.g., Alesina \& Gatti, 1995; Garriga, 2016; Persson \& Tabellini, 1999; Rogoff, 1985).

Nevertheless, inflation rate, as the monetary policy objective, is not only a phenomenon of monetary policy but also fiscal policy (Leeper and Leith 2016), so issues on fiscal-monetary interaction are crucial in determining monetary policy effectiveness. Sargent and Wallace (1981) illustrated that, in the long run, the monetary authority could lose its effectiveness to control the inflation rate when the monetary authority is assigned to accommodate the expenditure of the fiscal authority. Woodford (1995) also demonstrated that the inflation rate is the joint phenomenon of fiscal and 
monetary policy, which is transmitted through the government's intertemporal budget constraint. Blanchard (2004) portrayed the Brazilian inflationary periods as a problem where the Central bank forfeits its control over inflation due to substantial public debt issued by the fiscal authority. Bianchi and Ilut (2017) found that the ups and downs of inflation in the US are significantly influenced by the interaction of fiscal and monetary policy. Periods with the high fiscal imbalance constrain the effectiveness of the monetary authority then drive up the inflation rate.

Such an issue makes fiscal-monetary interactions crucial. Chadha and Nolan (2003) emphasized that the essential issue of interaction between fiscal and monetary policy relies on their behavior to stabilize the fluctuation of business cycles. However, fiscal policy persists to relatively procyclical, especially in developing countries, while monetary policy in the wide world tends to be more countercyclical, especially in Inflation Targeting Framework (ITF) countries (Vegh and Vuletin 2012; Warjiyo and Juhro 2019). Figure 1 portrays the cyclicality behavior of fiscal policy in 25 ITF countries. It shows that fiscal policy is procyclical in most developing-ITF countries, while fiscal policy in developed-ITF countries is countercyclical. A growing works of research has demonstrated this phenomenon is mainly driven by deteriorated institutions, high political distortion, constrained-International borrowing, and indiscipline fiscal policy in developing countries (Gavin and Perotti 1997; Tornell and Lane 1999; Talvi and Végh 2005; Alberola and Montero 2006; Woo 2008; Ilzetzki 2011; Park 2012; Boiciuc 2015; Alesina and Tabelli 2016). The figure also portrays that countries with procyclical fiscal policy tend to have a higher inflation rate than otherwise. Mcmanus and Ozkan (2015) demonstrated that countries with procyclical fiscal policy have higher inflation rates rather than otherwise. Procyclical fiscal policy excessively pushes the aggregate demand, over-heating the economy, therefore exacerbating inflation rates.

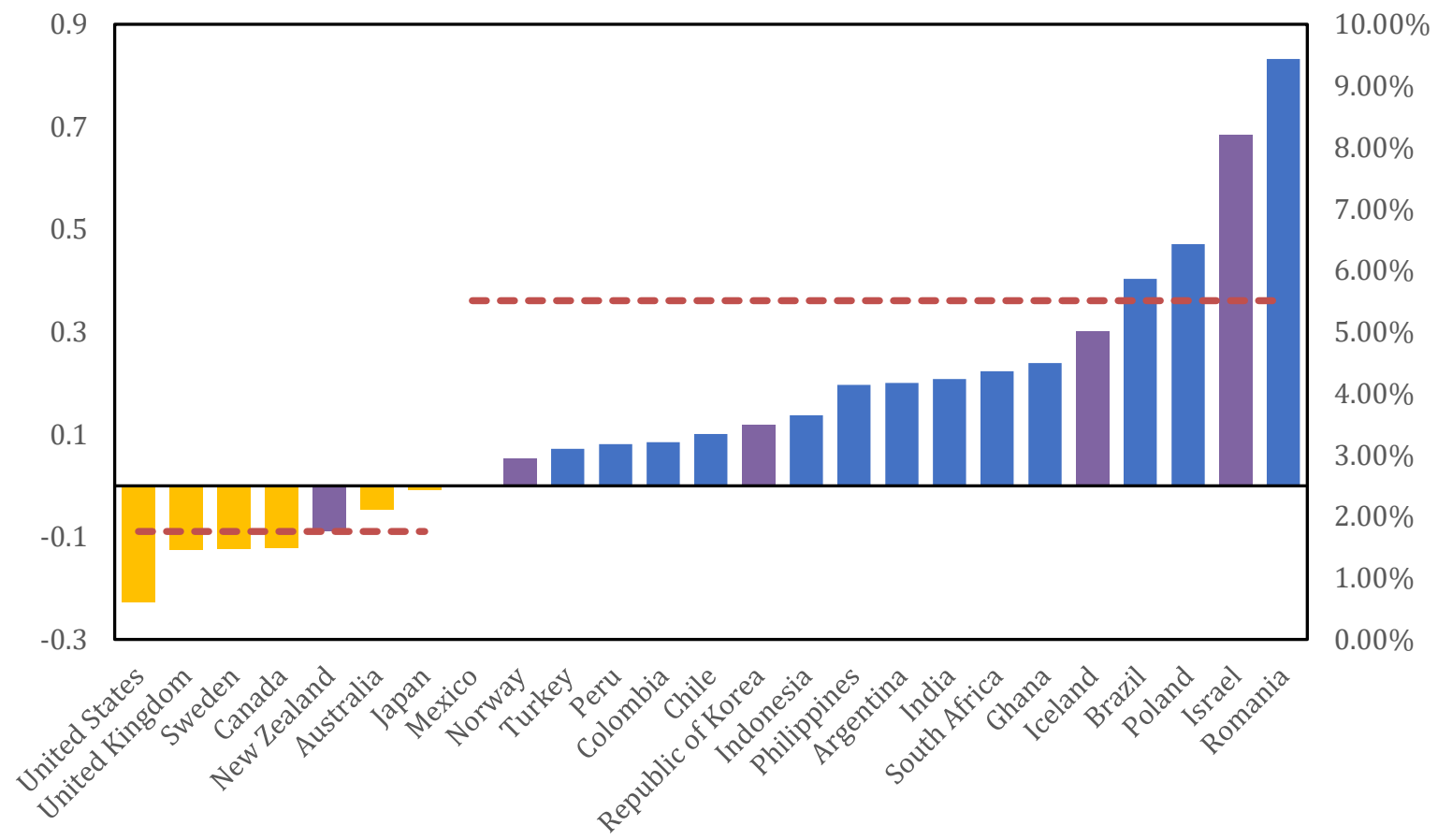

Figure 1. Fiscal Cyclicality and Average Inflation Rates in ITF Countries, 2003-2017

Source: International Financial Statistics (IFS) and World Economic Outlook, IMF.

Notes: The figure covers 25 selected ITF countries. For fiscal policy, a positive (negative) correlation indicates the procyclical (countercyclical) fiscal policy. The dashed line represents the average inflation rate of two groups of countries with countercyclical and procyclical fiscal policies. The cyclical components of GDP and Government Expenditure have been estimated using the Hodrick-Prescott Filter.

Several works of literature have also demonstrated that the procyclical fiscal policy could exacerbate monetary policy effectiveness. Frankel (2010) described that one structural feature that separates the less-effective and effective monetary policy is the cyclicality behavior of fiscal policy. Robert (2014) revealed that procyclical fiscal policy, due to less-developed financial markets, would complicate the conduct of monetary policy. The fiscal deficits due to procyclical fiscal policy would be accommodated by way of monetization. In regards to oil-dependent countries, 
Elbadawi, Goaied, and Tahar (2017) have shown that the flexible monetary regime requires a firm countercyclical fiscal policy to avoid the over-burdened monetary policy due to high oil-revenue volatility.

However, if indiscipline fiscal policy could affect the objective and the effectiveness of the monetary policy, is it necessarily mean that procyclical fiscal policy impacts monetary policy credibility? This issue becomes crucial as we have to carefully distinguish the credibility of monetary policy from monetary policy effectiveness. The effectiveness of monetary policy should be defined as the de facto ability of monetary policy instruments to influence monetary policy objectives, such as the inflation rate. For instance, Sargent and Wallace (1981) illustrated that monetary policy's ability in influencing the inflation rate would be diminished when the monetary authority is under government control. It implies that under a particular condition, monetary policy forfeits its effectiveness in affecting the inflation rate. For the credibility of monetary policy, it is defined as the commitment of monetary policy operation to achieve a particular target, so that the meaning of credibility is status quo, not de facto ability of monetary policy. Warjiyo and Juhro (2019) argued that the credibility of monetary policy is reflected by the ability of monetary policy in achieving the committed target.

This paper addresses the issue by examining the consequences of procyclical fiscal policy on the credibility of monetary policy. First, we construct a simple theoretical model in the tradition of Keynesian economics and Barro and Gordon (1983). Our model demonstrates that the more procyclical fiscal policy, the higher inflation rates at the constant monetary policy. In other words, it reflects the imperfect monetary policy transmission as the procyclical fiscal policy turns the monetary policy into more inflationary. The model afterward suggests that monetary policy possibly fails to set the actual, expected, and targeted inflation rates precisely at the same level when fiscal policy is procyclical. In response to this, the monetary authority could reattain its credibility by tightening monetary policy. On the other hand, this also implies that under the procyclical fiscal policy, the monetary policy requires to operate a tighter policy to achieve a particular rate of inflation so that monetary policy possibly becomes less effective.

Second, we conduct empirical investigations to test our hypothesis based on a dataset consisting of 25 selected ITF countries during 2003-2017. This paper first explores the empirical relationship between the cyclicality behavior of fiscal policy and inflation rates. We then wrap up the investigations by directly scrutinizing the empirical impact of cyclicality behavior of fiscal policy towards the credibility of monetary policy. By utilizing the Differenced Generalized Method of Moments (GMM), our empirical estimations suggest that procyclical fiscal policy significantly exacerbates the inflation rate. This finding is consistent with Mcmanus and Ozkan (2015) and Kaminsky, Reinhart, and Végh (2004), which demonstrated that countries with procyclical fiscal policy have higher inflation rates than otherwise. Procyclical fiscal policy excessively pushes the aggregate demand, over-heating the economy, therefore exacerbating inflation rates. Second, we find that the empirical relationship between cyclicality behavior of fiscal policy and the credibility of monetary is statistically insignificant, which implies that procyclical fiscal policy would not deteriorate the credibility of monetary policy. Since the monetary authority would directly respond to the potential distortion derived from procyclical fiscal policy circumstances, the monetary authority obviously would strive to keep its credibility by employing tighter monetary policy. Therefore, the monetary authority could assure its credibility by re-arrayed the targeted, expected, and actual inflation rates at the same level. This finding is consistent with the previous literature, which addressed that monetary policy would hold its credibility by a consistent response based on policy rule to achieve the policy objective (e.g., see Barro and Gordon 1983; Kydland and Prescott 1977; Fellner 1979; Mccallum 1984).

This paper contributes to the literature in several crucial ways. First, this paper is the first study providing the rational and empirical framework concerning the consequences of procyclical fiscal policy on monetary policy credibility. The existing works of literature put much emphasis on the role of fiscal policy in influencing the effectiveness of the monetary policy (e.g., Frankel 2010; Robert 2014; Elbadawi, Goaied, and Tahar 2017), while they have not formally addressed the determination of cyclical behavior of fiscal policy on the credibility of monetary policy. On the other hand, related literature on the determinants of monetary policy credibility primarily addressed the role of reputation, policy rule, and central bank independence while not explicitly mentioning the role of procyclical fiscal policy in affecting the credibility of monetary policy. Second, the topic of this paper is essential in policy practices given the critical role of monetary policy credibility in the ITF regime and the issues of procyclical fiscal policy in most ITF central in developing countries (see Figure 1).

The rest of this paper is organized as follows. Section II discusses the theoretical aspect by which expressed in the mathematical models and narrative propositions. Section III elaborates on the empirical strategy relating to the econometric method, data, and variables. Section IV relates to the discussion of empirical findings. Section V provides both concluding remarks and some policy implications. 


\section{The Models}

\subsection{Cyclicality Behavior of Fiscal Policy and Inflation Rates}

We replicate the Three Keynesian Equations to develop the building blocks of our research hypothesis. Let us now start with the IS-LM model. The objective of this model is to construct a theoretical relationship between the cyclicality behavior of fiscal policy and inflation rates. Firstly, we assume that the economy contains three sectors:

$$
Y=C(Y d)+I(r)+G(Y)
$$

where,

$$
\begin{gathered}
C=C_{0}+\alpha_{1}(Y d) ; Y d=Y-T x \\
C=C_{0}+\alpha_{1} Y-\alpha_{1} T x \\
I=I_{0}-\alpha_{2} r \\
G=G_{0}+\alpha_{3} Y ; \text { If } \alpha_{3}\left\{\begin{array}{c}
>\text {, Procyclical } \\
=0, \text { Acyclical } \\
<0, \text { Countercyclical }
\end{array}\right.
\end{gathered}
$$

Where $Y, Y d r, C, I, G$, and $T x$ are aggregate output, disposable income, interest rates, domestic consumption, domestic investment, government expenditure, and lumpsum tax revenue, respectively.

According to the standard model of aggregate demand, government expenditure is exogenous or acyclical. However, government expenditure frequently contains a cyclical component - or it responds to the business cycles in various ways. Parameter of $\alpha_{3}$ explain that there is a response from government expenditure due to changes in output level - it could be positive (procyclical), negative (countercyclical), or zero (acyclical).

Hence, the equilibrium of real sector (IS) is expressed as follows:

$$
Y=\frac{\varphi}{\alpha_{4}}-\frac{\alpha_{2}}{\alpha_{4}} r
$$

Where $\varphi=C_{0}+I_{0}+G_{0}-\alpha_{1} T x$ dan $\alpha_{4}=\left(1-\alpha_{1}-\alpha_{3}\right)$. Then we obtain the equilibrium of demand and supply of money as follows:

$$
\frac{M^{d}}{P}=\beta_{1} Y-\beta_{2} r
$$

Where $\frac{M^{d}}{P}=\frac{M^{d}}{P}$,

$$
\begin{aligned}
& \frac{M^{s}}{P}=\beta_{1} Y-\beta_{2} r \\
& r=\beta_{4} Y-\beta_{3} \frac{M^{s}}{P}
\end{aligned}
$$

Where $M^{s}, M^{d}, r$, and $P$ are money supply, money demand, interest rates, and price level. For the coefficients, $\beta_{3}=\left(\frac{1}{\beta_{2}}\right)$ and $\beta_{4}=\left(\frac{\beta_{1}}{\beta_{2}}\right)$. Then we define the equilibrium of IS-LM as follows: 


$$
P=\frac{\alpha_{2} \beta_{3}\left(M^{s}\right)}{\left(\alpha_{4}+\alpha_{2} \beta_{4}\right) Y-\varphi} \Leftrightarrow P=\frac{\alpha_{2} \beta_{3}\left(M^{s}\right)}{\left(1-\alpha_{1}-\alpha_{3}+\alpha_{2} \beta_{4}\right) Y-\varphi}
$$

By assuming that $Y$ and $M^{s}$ are not changing, we re-write equation (6) in a form where the price level is a function of fiscal cyclicality behavior $\alpha_{3}$, as follows:

$$
P=f\left(\alpha_{3}\right) \text { for } P^{\prime}\left(\alpha_{3}\right)>0
$$

According to equation (7), the relationship between fiscal cyclicality behavior and the price level is positive (see Proposition 1). This is consistent with Kaminsky, Reinhart, and Végh (2004) and Mcmanus and Ozkan (2015), who revealed that the procyclical fiscal policy could affect the inflation rates by "turning sunny days into scorching infernos": procyclical government expenditure would excessively boost the aggregate demand, set the economy into the "over-heated" circumstances, therefore soaring the inflation rates.

Proposition 1. When fiscal policy tends to be more procyclical (countercyclical), indicated by increases (decreases) in $\alpha_{3}$, the price level would be increased (decreased).

\subsection{The Credibility of Monetary Policy and Cyclicality Behavior of Fiscal Policy}

We adapt Barro and Gordon's (1983) seminal work of monetary policy credibility model by augmenting the role of fiscal policy in the ITF setup. In contrast to the original model, we assume that the monetary policy transmissions are imperfect which is indicated by the additional impact of cyclicality behavior of fiscal policy (see Proposition 1), thereby it expressed as follows:

$$
\pi=\mu+\beta \gamma \text { for } \beta>0
$$

Where $\pi$ is the inflation rate, $\mu$ denotes the money growth, and $\gamma$ represents the degree of fiscal cyclicality with $\beta$ as the parameter of $\gamma$.

Nowadays, most of the central banks implement the Inflation Targeting Framework (ITF) by bearing the sacrifice ratio in mind (i.e., forgone output cost due to stable and low inflation rates). In other words, it indicates that the credible monetary policy will always be countercyclical. Therefore, the central bank has an objective to minimize the single-period loss function by that expressed as follows:

$$
L=a\left(\pi-\pi^{*}\right)^{2}+\left(y-y^{*}\right)^{2} ; y^{*}=k \cdot y^{n}
$$

Where $\pi^{*}, y, y^{*}, y^{n}$, and $k$ are targeted inflation rates, output level, targeted output level, potential output, and temptation parameter.

However, the central bank is constrained by the trade-off between inflation rates and output level in which to achieve low inflation rates, the central bank must sacrifice some of the output, ceteris paribus. Such a constraint is expressed through the Lucas supply shock as follows:

$$
y=y^{n}+b\left(\pi-\pi^{e}\right)
$$

Where $\pi^{e}$ inflation rates.

By substituting equations (8) and (10) on equation (9), we obtain an equilibrium of loss function as follows:

$$
L=a\left(\mu+\beta \cdot \gamma-\pi^{*}\right)^{2}+\left[(1-k) y^{n}+b\left(\mu+\beta \cdot \gamma-\pi^{e}\right)\right]^{2}
$$

Then, we take the first-order condition on equation (4) to obtain the optimal combination of cyclicality behavior fiscal policy and each variable that minimizes the loss function: 


$$
\begin{gathered}
\frac{\partial L}{\partial \gamma}=0 \\
\frac{\partial L}{\partial \gamma}=-\frac{\left(a+b^{2}\right) \mu-a\left(\pi^{*}\right)+b(1-k) y^{n}-b^{2}\left(\pi^{e}\right)}{\beta\left(a+b^{2}\right) \gamma}=0 \\
\gamma=-\frac{\left(a+b^{2}\right) \mu-a\left(\pi^{*}\right)+b(1-k) y^{n}-b^{2}\left(\pi^{e}\right)}{\beta\left(a+b^{2}\right)}
\end{gathered}
$$

Afterward, the model assumes that the monetary policy is time consistent, $k=0$, or it implies targeted output equals to its potential, and the central bank set the targeted inflation rates equals to zero. Then the equation is obtained as follows:

$$
\gamma=-\frac{1}{\beta} \mu+\frac{b^{2}}{\beta\left(a+b^{2}\right)} \pi^{e}
$$

Figure (2) below combines the curve of equations (8) and (13). It implies that at $\gamma_{0}$ (i.e., countercyclical fiscal policy), the targeted inflation is equaled to actual and expected inflation rates, ceteris paribus. In contrast, if the cyclicality behavior of fiscal policy occurs at $\gamma_{0}$ then it would create a gap between targeted, actual, and expected inflation rates.

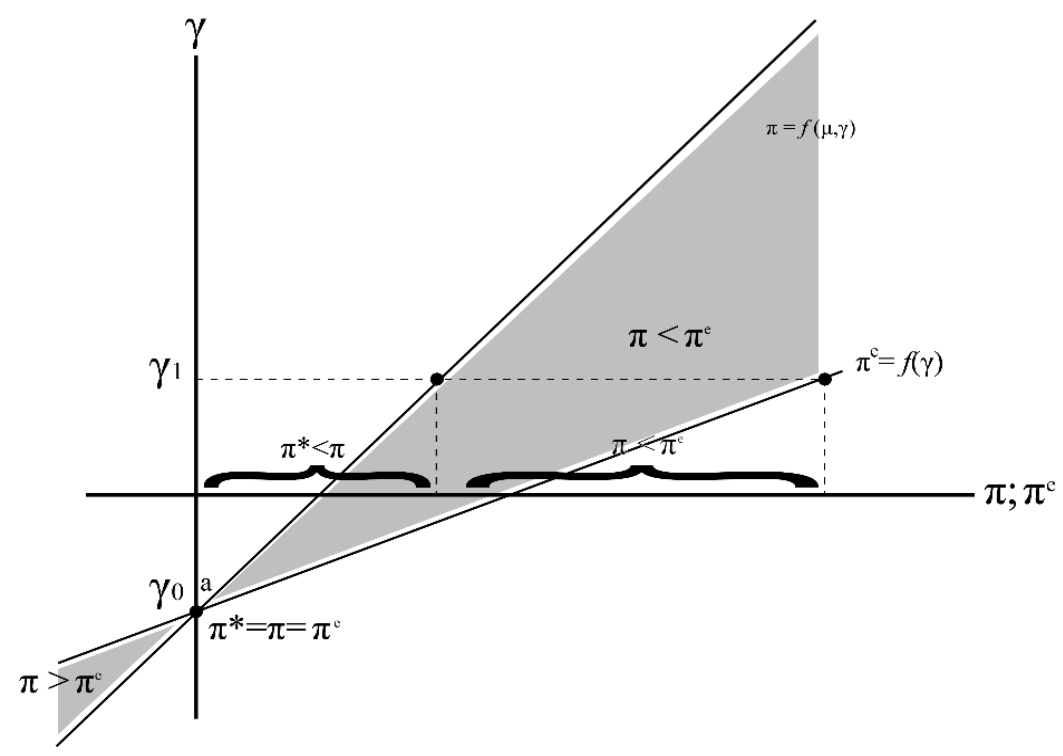

Figure 2. Cyclicality Behavior of Fiscal Policy and Rates of Targeted, Actual, and Expected Inflation

Proposition 2. The procyclical fiscal policy produces a divergence among targeted, actual, and expected inflation rates $\left(\pi \neq \pi^{e} \neq \pi^{*}\right)$. As such, the public fails to form the expected rate of inflation correctly due to unharmonized measures of both monetary and fiscal authority.

Figure 2 demonstrates that there are two circumstances characterized by the degree of the cyclicality behavior of fiscal policy. The first circumstance (i.e., procyclical fiscal policy) is indicated by a deviation on targeted, actual, and expected inflation rates. By contrast, the second circumstance (i.e., countercyclical fiscal policy) is characterized by an equal rate of targeted, actual, and expected inflation.

$L_{a}$ denotes the loss function under the first circumstance. The loss function equation elaborated as follows:

$$
L_{a}=a\left(\pi-\pi^{*}\right)^{2}+\left[(1-k) y^{n}+b\left(\pi-\pi^{e}\right)\right]^{2} ; \pi \neq \pi^{e} \neq \pi^{*} ; \gamma_{1} ; k=1
$$

Equation (14) suggests that under the procyclical fiscal policy, the monetary authority's credibility is distorted by the procyclical fiscal policy. Therefore, the loss function of the first circumstances will always be more than zero. 


$$
\boldsymbol{L}_{\boldsymbol{a}}=\left(\Delta \boldsymbol{\pi}_{\text {tar }}\right)^{2}+\left[\boldsymbol{b}\left(\Delta \boldsymbol{\pi}_{\text {exp }}\right)\right]^{2} ; \boldsymbol{L}_{\boldsymbol{a}}>\mathbf{0}
$$

Where $\Delta \pi_{t a r}=\left(\pi-\pi^{*}\right)$ and $\Delta \pi_{\text {exp }}=\left(\pi-\pi^{e}\right)$.

Under the second circumstance, the loss function denoted by $L_{b}$, which elaborated the equation of $L_{b}$ mathematically expressed as follows:

$$
L_{b}=a\left(\pi-\pi^{*}\right)^{2}+\left[(1-k) y^{n}+b\left(\pi-\pi^{e}\right)\right]^{2} ; \pi=\pi^{e}=\pi^{*} ; \gamma_{0} ; k=1
$$

The total loss under the second circumstance will always be equal to zero. It implies that under the countercyclical fiscal policy, the monetary policy achieves its optimal credibility; therefore, fiscal policy becomes an excellent complementary for monetary policy.

$$
L_{b}=\mathbf{0}
$$

Proposition 3. The procyclical fiscal policy malevolently exacerbates the credibility of monetary policy as the monetary policy fails to keep its commitment $\left(L_{a}>0\right)$. By contrast, the countercyclical fiscal policy helps monetary policy to attain its credibility $\left(L_{b}=0\right)$.
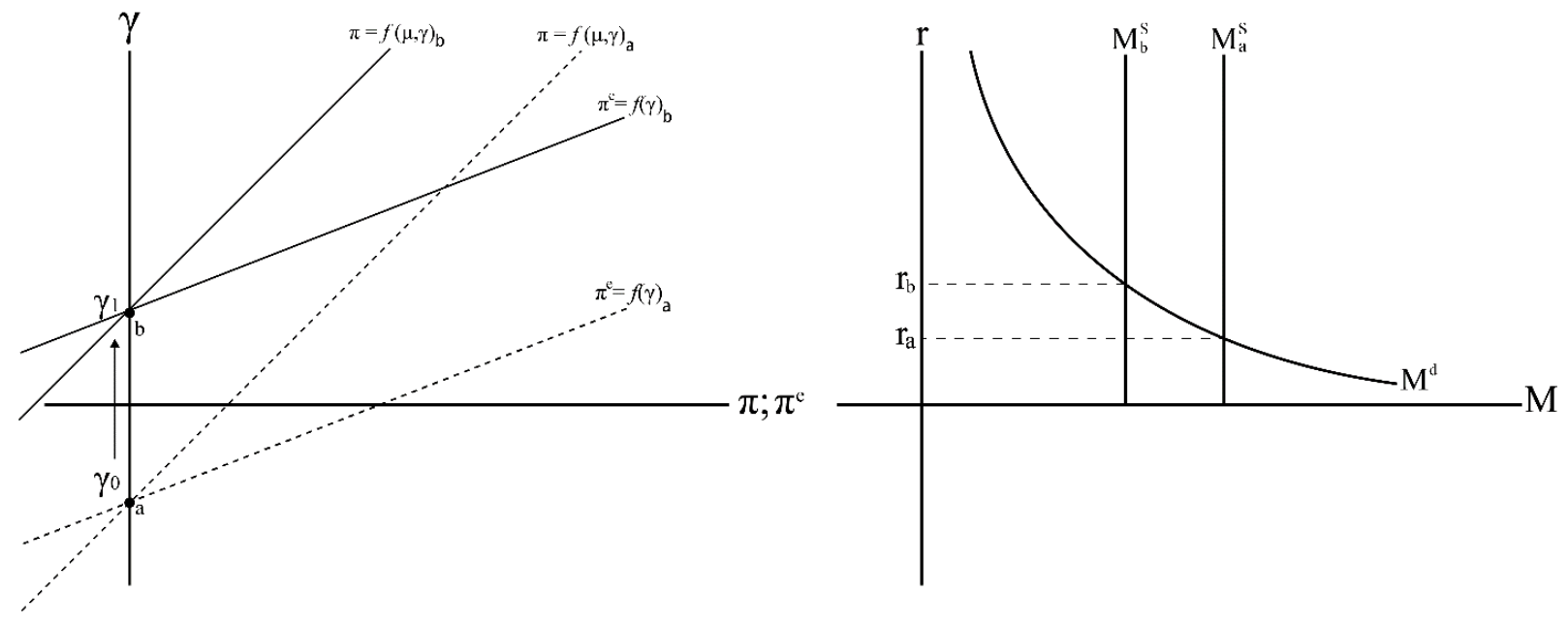

Figure 3. Monetary Policy Response to the Procyclical Fiscal Policy

However, the monetary authority could attain its credibility back by a tighter monetary policy (see figure 3 ). The monetary authority employs a negative money growth policy, also significantly higher interest rates, to adjust the deviation between targeted, expected, and actual inflation rates. Therefore, government expenditure increases would cause the crowding-out effect which is indicated by the tighter monetary policy under the procyclical fiscal policy. Graphically, tighter monetary policy would shift the equilibrium of equations (8) and (13) from its initial optimal point a to its new optimal point at $b$.

Proposition 4. Contractionary monetary policy could adjust the deteriorated monetary policy credibility by employing a negative money growth policy and significantly higher interest rates.

\section{Empirical Strategy}

\subsection{Data}

We construct a dataset comprised of 375 observations. It covers 25 selected-ITF countries including Argentina, Australia, Brazil, Canada, Chile, Colombia, Ghana, Iceland, India, Indonesia, Israel, Japan, Mexico, New Zealand, Norway, Peru, Philippines, Poland, Republic of Korea, Romania, South Africa, Sweden, Turkey, United Kingdom, and the United States from 2003 until 2017 (see Appendix A).

We explore several works of literature, formal law document, and press release from the central bank to list down the ITF countries. First, Hammond (2012) elaborates on 21 ITF countries consisting of Australia, Brazil, Canada, Chile, Colombia, Ghana, Iceland, Indonesia, Israel, Mexico, New Zealand, Norway, Peru, Philippines, Poland, Republic of 
Korea, Romania, South Africa, Sweden, Turkey, and United Kingdom. Second, Reserve Bank of India Act, 1934 (As amended by the Finance, No. 2, Act, 2019), Chapter IIIF Monetary Policy, Point 45ZA documents the formal direction in adopting ITF for India. Third, Argentina's inflation targeting regime Press Conference on September 26, $2016^{1}$. Lastly, the FOMC meeting minutes on January 25, 2012, explains that the Federal Reserves (the Fed) officially reached a broad agreement on the following principles regarding its longer-run goals and monetary policy strategy, promoting maximum employment, stable prices, and moderate long-term interest rates by formally set the medium-term inflation rates at 2 percent.

\subsection{Identifying the Variables}

\subsubsection{The Credibility of Monetary Policy}

A growing literature has shown that there are numerous technical approaches to define the extent of monetary policy credibility empirically. Warjiyo and Juhro (2017) interpret monetary policy credibility as the deviation of realized and targeted inflation which implies that the more deviation widened, the less monetary policy credibility attained. Fritsche, Slacalek, and Dovern (2009) and Kabundi and Mlachila (2018) technically define the monetary policy credibility as the inflation forecast disagreement among forecasters which indicates less disagreement implies higher monetary policy credibility. In other words, it suggests that monetary policy credibility increases when inflation becomes more predictable. Whereas, Zeng (2018) identifies the extent of monetary policy credibility with inflation persistence whereby it reflects public responsiveness to monetary policy.

Although these definitions are diverse by the technical approach, the spirit naturally belongs to the core values of the Credibility Hypothesis $(\mathrm{CH})$. In verbatim, $\mathrm{CH}$ articulated as the foregone output costs of a disinflationary episode will be smaller if the public correctly believes that the attempt will not be abandoned (see Fellner 1979). Cukierman (1986) also suggests that monetary policy credibility inherently relates to the inflationary expectation which, in turn, reflects the public's evaluation of monetary policy credibility. In other words, it implies that the credible monetary policy is the outcome of harmonized interaction between public and monetary authority which is indicated by the successful measures of the monetary authority to set the realized and expected inflation precisely, or at least approximately at the same level.

Therefore, by consistently standing along with the $\mathrm{CH}$, we calculate the monetary policy credibility as the deviation between the actual and expected rate of inflation, which is expressed as follows:

$$
C M P=\frac{\left|\pi-\pi^{e}\right|}{\left(1+\left|\pi-\pi^{e}\right|\right)} \times 100
$$

Where $C M P, \pi$, and $\pi^{e}$ are the credibility of monetary policy, actual inflation rates, and expected inflation rate, respectively. The credibility indicator suggests that the less credible monetary policy is reflected by higher CMP, vice versa. Besides, expected inflation would be estimated using the Hodrick-Prescott Filter (HP-Filter). Correia, Neves, and Rebelo (1995) explain that the backward-forward model estimation of HP Filter makes it well-performed to measure an approximate value of expected inflation rates.

\subsubsection{The Cyclicality Behavior of Fiscal Policy}

The cyclicality behavior of fiscal policy relates to the responses of fiscal policy (e.g., tax, spending, and budget deficit/surplus policy) towards the fluctuation of business cycles. Fiscal policy becomes procyclical when fiscal authority responds to the economic expansion (recession) by expansionary (contractionary) fiscal policy, vice versa (Kaminsky, Reinhart, and Végh 2004).

There are several approaches to identify fiscal policy cyclicality behavior relating to the selected variable and measurement technique. Tornell and Lane (1999), Talvi and Végh (2005), Ilzetzki (2011), Park (2012), Frankel, Vegh, and Vuletin (2013) used government spending, whereas Kaminsky, Reinhart, and Végh (2004) and Camous and Gimber (2018) used tax revenue as the fiscal instrument proxy. It shows that government spending is frequently applied to identify fiscal policy cyclicality behavior instead of tax revenue. Park (2012) argues that the revenue side approach leads to biased estimation of fiscal cyclicality because its component inherently correlated with business cycles.

Furthermore, most of the research frequently employs a regression approach to identify the fiscal policy cyclicality behavior coefficient. However, those papers are focused on the determinant factors of fiscal cyclicality behavior. In contrast, this paper utilizes fiscal cyclicality behavior as an independent variable. Thus, this paper operates a 20 -year

\footnotetext{
${ }^{1}$ https://www.bcra.gob.ar/Noticias/Regimen_de_Metas_de_Inflacion_en_Argentina_i.asp (Accessed on March, 2020)
} 
window $(n=20)$ rolling correlation of the first-differenced of both government expenditure and Gross Domestic Product (GDP) to obtain cyclicality coefficient for each individual and time observation (refers to Frankel, Vegh, and Vuletin 2013). Specifically, the measurement of fiscal cyclicality behavior is calculated as follows:

$$
\begin{gathered}
\hat{\sigma}_{12, t}^{2}(n)=\frac{1}{n-1} \sum_{i=0}^{n}\left(y_{1 t}-\widehat{\mu_{1 t}}(n)\right)\left(y_{2 t}-\widehat{\mu_{2 t}}(n)\right) \\
\hat{\rho}_{12, t}(n)=\frac{\hat{\sigma}_{12, t}^{2}(n)}{\hat{\sigma}_{1, t}^{2}(n) \times \hat{\sigma}_{2, t}^{2}(n)} \\
\hat{\rho}_{12, t}\left\{\begin{array}{c}
1 \geq \hat{\rho}_{12, t}>0 \text {, for procyclical fiscal policy } \\
\hat{\rho}_{12, t}=0 \text {, for acyclical fiscal policy } \\
-1 \leq \hat{\rho}_{12, t}<0 \text {, for countercyclical fiscal policy }
\end{array}\right.
\end{gathered}
$$

Where $\hat{\sigma}_{12, t}^{2}(n)$ is the covariance of variables $y_{1 t}$ and $y_{2 t}$ for 1 and 2 are the first-differenced of government expenditure and the output, respectively; $\hat{\rho}_{12, t}(n)$ is the rolling correlation coefficient of two variables; $n$ is the number of observations or in other words is a rolling window; $\widehat{\mu_{1 t}}(n)$ and $\widehat{\mu_{2 t}}(n)$ respectively, are the average values of $y_{1 t}$ and $y_{2 t}$ of the number of observations in the rolling window.

\subsection{Econometric Method}

This paper performs GMM for both model estimates. In a panel data structure analysis, GMM is frequently utilized in examining the empirical evidence on inflation rates determinant factors specifically for small period observation (e.g., Cottarelli 1998; Bjørnstad and Nymoen 2008; Kim, Lin, and Wu 2014; Deniz, Tekce, and Yilmaz 2016; Ferreira Arruda, Oliveira de Olivindo, and Castelar 2018; Bakas and Chortareas 2019).

Naturally speaking, inflation rates and the credibility of the monetary policy contain the role of expectation adaptive or inertia, represented by the Lagged Dependent Variable (LDVs) in the econometric model (e.g., Moreira 2012; Mcmanus and Ozkan 2015). Since the LDV would be correlated with the Composite Error Term (CET) by construction (i.e., endogeneity problem), The standard panel data regression thus leads to biased and inconsistent estimation (Baltagi 2005). To overcome the endogeneity problem, Arellano and Bonds (1991) provide the Standard GMM in the first differenced equation which utilizes the orthogonality conditions that exist between LDV and the CET as the Instrumental Variables (IV). Suppose we use the autoregressive equation in the first difference form equation with a one-way error component which is expressed as follows:

$$
\begin{gathered}
\left(y_{i, t}-y_{i, t-1}\right)=\delta\left(y_{i, t-1}-y_{i, t-2}\right)+\left(\mu_{i}-\mu_{i}\right)+\left(v_{i, t}-v_{i, t-1}\right) \\
\left(y_{i, t}-y_{i, t-1}\right)=\delta\left(y_{i, t-1}-y_{i, t-2}\right)+\left(v_{i, t}-v_{i, t-1}\right)
\end{gathered}
$$

Where $y_{i, t}, \mu_{i}, v_{i, t}$, and $\delta$ are dependent variables at time $t$, unobserved individual-specific component (fixed effect), idiosyncratic term, and parameter of LDV, respectively. An annex, the equation assumed that $\mu_{i} \sim I I D\left(0, \sigma_{\mu}^{2}\right)$ and $v_{i, t} \sim \operatorname{IID}\left(0, \sigma_{v}^{2}\right)$.

From equation (20), $y_{i, t-2}$ is the valid instrumental variable since it is uncorrelated with $\left(v_{i, t}-v_{i, t-1}\right)$ and correlated with $\left(y_{i, t-1}-y_{i, t-2}\right)$. Thus, as a big picture, we could obtain the instrumental variable matrix for specific $(i)$ individual observations $\left(W_{i}\right)$ for $t=T$ as follows:

$$
W_{i}=\left[\begin{array}{cccc}
{\left[y_{i 1}\right]} & \ldots & & 0 \\
& {\left[y_{i 1}, y_{i 2}\right]} & & \\
0 & \ldots & & {\left[y_{i 1}, \ldots, y_{i, T-1}\right]}
\end{array}\right]
$$

Therefore, the instrumental variables for each observation are $W=\left[W_{1}^{\prime}, W_{2}^{\prime}, \ldots, W_{N}^{\prime}\right]^{\prime}$ and moments condition equation is $E\left(W_{i}^{\prime} \Delta v_{i}\right)=0$, where $v_{i}^{\prime}=\left(v_{i, 3}-v_{i, 2}, \ldots, v_{i, T}-v_{i, T-1}\right)$. Afterward, we obtain the instrumental variables equation form for the standard GMM model as follows: 


$$
W^{\prime} \Delta y=W^{\prime} \Delta y_{-1} \delta+W^{\prime} \Delta v
$$

For the models with exogenous variables, if there are additional strictly exogenous regressors $x_{i, t}$ with $E\left(x_{i, t}, v_{i, t}\right)=$ 0 but correlated with $\mu_{i}$, for all $t=1,2,3, \ldots, T$, then $x_{i, t}$ are valid instrumental variables for the first-differenced equation, $Z_{i}=\left[x_{i, 1}, x_{i, 2}, \ldots, x_{i, T}\right]$ and $Z^{\prime}=\left[Z_{1}^{\prime}, Z_{2}^{\prime}, \ldots, Z_{T}^{\prime}\right]$. In this regard, equation (21) becomes:

$$
Z^{\prime} \Delta y=Z^{\prime}\left(\Delta y_{-1}\right) \delta+Z^{\prime}(\Delta X) \beta+Z^{\prime} \Delta v
$$

By performing Generalized Least Square (GLS) on equation (22) or (23), we get the consistent one-step estimator $\left(\widehat{\delta_{1}}\right)$, whereas a two-step consistent estimator $\left(\widehat{\delta_{2}}\right)$ obtained by utilizing the Optimal GMM Estimator (Baltagi 2005).

Furthermore, this method relies on two specification tests that must be satisfied. The first one relates to the validity of IV. Arellano and Bond (1991) recommend the Hansen Test (HT) for this regard. Technically, the ST utilizes a distribution value of chi-squared $\left(\chi^{2}\right)$. The IV are valid when the probability of $\chi^{2}$ is higher than the confidence level (viz. 5 percent). The second one relates to the test of autocorrelation at time $t$ and $t-2$. Arellano and Bond (1991) develop an autocorrelation test by utilizing the Z-statistic. When the probability of Z-statistic is higher than the confidence level, it indicates that the autocorrelation problem unburdens the estimation. Eventually, the estimate could overcome the unbiased and inconsistent parameters when these specification tests are fully satisfied.

\subsection{Specifying the Model Estimates}

We begin by specifying the first model estimates which are intended to scrutinize the empirical relationship between cyclicality behavior of fiscal policy and inflation rates. It follows the standard determinant of an inflation rate that includes money growth rate, exchange rate, unemployment rate, public debt, and central bank independence as the control variables commonly mentioned in several works of research (see Woodford 1995; Cottarelli 1998; Kim, Lin, and Wu 2014; Bjørnstad and Nymoen 2008; Mcmanus and Ozkan 2015; Alisa 2015; Deniz, Tekce, and Yilmaz 2016; Garriga 2016; Ferreira Arruda, Oliveira de Olivindo, and Castelar 2018; Bakas and Chortareas 2019). Explicitly, the first model estimate specified as follows:

$$
\pi_{i, t}=\alpha_{0}+\delta_{1} \pi_{i, t-1}+\alpha_{1} \hat{\rho}_{i, t}+\gamma \boldsymbol{Z}_{i, t}+u_{i, t}
$$

Where $\pi, \hat{\rho}, \gamma \boldsymbol{Z}$ are inflation rate, cyclicality behavior of fiscal policy, and vector of parameter and controlled variables, respectively.

Let us now specify the second model estimate which is designed to address the empirical relationship between the credibility of monetary policy and cyclicality behavior of fiscal policy. For the model specification, we utilize the lagged value of monetary policy credibility, central bank independence, central bank transparency, and public debt (e.g., see Moreira 2012; Warjiyo and Juhro 2019; Mackiewicz-Łyziak 2016). The model specification is expressed as follows:

$$
C M P_{i, t}=\alpha_{0}+\delta_{2} C M P_{i, t-1}+\alpha_{2} \hat{\rho}_{i, t}+\tau \boldsymbol{W}_{i, t}+u_{i, t}
$$

Where $C M P, \hat{\rho}, \tau \boldsymbol{W}$ are the credibility of monetary policy, cyclicality behavior of fiscal policy, and vector of parameter and controlled variables, respectively.

Table 1. Model Selection

\begin{tabular}{ccc}
\hline & First Model Estimate & Second Model Estimate \\
\hline$\delta_{P L S}$ & 0.608144 & 0.395233 \\
$\delta_{F E}$ & 0.444823 & 0.243578 \\
$\delta_{F D-G M M}$ & 0.130684 & 0.392122 \\
\hline \multirow{2}{*}{ Conclusion } & $\delta_{F D-G M M}<\delta_{F E}<\delta_{P L S}$ & $\delta_{F E} \ll \delta_{F D-G M M}<\delta_{P L S}$ \\
& System GMM & First Differenced GMM \\
\hline
\end{tabular}


Table 1 exhibits the results of model selection for the first and second model estimates. In deciding whether the differenced GMM is the best-fit estimator or system GMM instead, we follow the standard procedure suggested by (Roodman 2009). In this regard, we compare the coefficient of LDV produced by pooled least squared $\left(\delta_{P L S}\right)$, standard panel fixed-effect $\left(\delta_{F E}\right)$, and the differenced GMM $\left(\delta_{F D-G M M}\right)$. The LDV's coefficient estimated using pooled least squared is considered as being biased upward while the the coefficient from fixed-effect estimation tens to be bias downward (Bond 2002). When $\delta_{F D-G M M}$ lies above or closer to $\delta_{P L S}$ than to $\delta_{F E}$ so that the diffenced GMM is the best-fit estimator rather than system GMM, vice versa. Our results demonstrate that system GMM is the best-fit estimator for the first model estimate, while the differenced GMM is for the second model estimate.

\section{Results and Discussion}

\subsection{Estimation Results}

The discussion began by exploring the empirical evidence of the influence of fiscal cyclicality on the inflation rate. For the specification tests, our results show that the estimations are valid in terms of the validity of the IV and have no autocorrelation. Table 2 demonstrates that Hansen J-test for over-identification test results in insignificant Chi-squared, implying that the instrumental variables used in the model are valid. The second-order autocorrelation test also implies the same in which exhibits insignificant correlation between the error-terms and the second lag of error terms.

As it is also portrayed in Table 2, the estimations confirm our hypothesis that the cyclicality behavior of fiscal policy consistently has a positive effect on the inflation rates. More specifically, it suggests that when the fiscal policy tends to be more procyclical by one percent, it increases the inflation rate by around 0.016 to 0.045 percent. This finding is consistent with previous works of literature. Kaminsky, Reinhart, and Végh (2004) and Mcmanus and Ozkan (2015) revealed that the procyclical fiscal policy could affect the inflation rates by "turning sunny days into scorching infernos": procyclically expansions in government expenditure would excessively boost the aggregate demand, set the economy into the "over-heated" circumstances, therefore soaring the inflation rates.

Table 2. First Model Estimate: Fiscal Cyclicality on Inflation

\begin{tabular}{|c|c|c|c|c|c|}
\hline & $(1)$ & (2) & (3) & (4) & $(5)$ \\
\hline Inflation (-1) & $\begin{array}{c}0.6837364 * * * \\
(0.0939576)\end{array}$ & $\begin{array}{c}0.4263846 * * * \\
(0.0669685)\end{array}$ & $\begin{array}{c}0.4346085 * * * \\
(0.0700254)\end{array}$ & $\begin{array}{c}0.4117479 * * * \\
(0.0716653)\end{array}$ & $\begin{array}{c}0.4135587 * * * \\
(0.0775415)\end{array}$ \\
\hline Fiscal Cyclicality & $\begin{array}{c}0.0151135 \\
(0.0109057)\end{array}$ & $\begin{array}{c}0.0225427 * * \\
(0.0098271)\end{array}$ & $\begin{array}{c}0.0209516 * * \\
(0.0100322)\end{array}$ & $\begin{array}{c}0.0223767 * * \\
(0.0100968)\end{array}$ & $\begin{array}{c}0.0224188 * * \\
(0.0104036)\end{array}$ \\
\hline $\begin{array}{l}\text { Broad } \\
\text { Growth }\end{array}$ & & $\begin{array}{c}0.0011538 \\
(0.0002859)\end{array}$ & $\begin{array}{c}0.0011368 * * * \\
(0.0002862)\end{array}$ & $\begin{array}{c}0.0010742 * * * \\
(0.0002744)\end{array}$ & $\begin{array}{c}0.0010776 * * * \\
(0.0002718)\end{array}$ \\
\hline Unemployment Rate & & & $\begin{array}{l}-0.0323605 \\
(0.0536407)\end{array}$ & $\begin{array}{c}-0.0310448 \\
(0.0527892)\end{array}$ & $\begin{array}{l}-0.0299462 \\
(0.053715)\end{array}$ \\
\hline Debt to GDP Ratio & & & & $\begin{array}{c}-0.0000617 * * \\
(0.0000251)\end{array}$ & $\begin{array}{c}-0.0000602 * * \\
(0.0000257)\end{array}$ \\
\hline $\begin{array}{ll}\text { Central } & \text { Bank } \\
\text { Independence } & \end{array}$ & & & & & $\begin{array}{l}-0.0004591 \\
(0.010031)\end{array}$ \\
\hline Constant & $\begin{array}{r}0.0103106 * * \\
(0.0044934) \\
\end{array}$ & $\begin{array}{l}0.0062384 * \\
(0.0034204) \\
\end{array}$ & $\begin{array}{r}0.0088405 \\
(0.0053951) \\
\end{array}$ & $\begin{array}{r}0.0131285^{* *} \\
(0.0059649) \\
\end{array}$ & $\begin{array}{c}0.0131242 \\
(0.0083691) \\
\end{array}$ \\
\hline $\begin{array}{l}\text { Overidentification } \\
\text { Test (Hansen J-test) }\end{array}$ & 23.14 & 21.32 & 20.46 & 18.88 & 18.88 \\
\hline $\begin{array}{l}\text { AR (2) Test } \\
\text { Wald Statistics }\end{array}$ & $\begin{array}{c}0.76 \\
94.99 * * *\end{array}$ & $\begin{array}{c}0.65 \\
171.33 * * *\end{array}$ & $\begin{array}{c}0.66 \\
216.45^{* * *}\end{array}$ & $\begin{array}{c}0.64 \\
274.99 * * *\end{array}$ & $\begin{array}{c}0.69 \\
304.12 * * *\end{array}$ \\
\hline $\begin{array}{l}\text { Instrumental } \\
\text { Variables }\end{array}$ & 20 & 20 & 20 & 20 & 20 \\
\hline $\begin{array}{l}\text { Number } \\
\text { Observation }\end{array}$ & 338 & 338 & 338 & 338 & 338 \\
\hline $\begin{array}{l}\text { Number of Countries } \\
\text { Estimator }\end{array}$ & $\begin{array}{c}25 \\
\text { System GMM }\end{array}$ & $\begin{array}{c}25 \\
\text { System GMM }\end{array}$ & $\begin{array}{c}25 \\
\text { System GMM }\end{array}$ & $\begin{array}{c}25 \\
\text { System GMM }\end{array}$ & $\begin{array}{c}25 \\
\text { System GMM }\end{array}$ \\
\hline
\end{tabular}

Notes: The asterisk denotes statistical significance *, **, and *** at 10 percent, 5 percent, and 1 percent, respectively. Numbers in the parentheses ( ) represent robust standard error.

For the rest of the variables, we find that increases in broad money growth significantly lift the inflation rates. It suggests that levitation money in the circulation brings the inflation rates to soared: since the money has a neutral effect on real income, then when the money growth exceeds the rate of economic growth, it would be absorbed as increases in the price level (Sidrauski 1967; Friedman 1968). For the public debt, we find evidence suggesting the significance of 
public debt size on inflation rates. It indicates that the magnificent size of public debt could reduce the inflation rate, and we argue that it is a matter of the market structure of public debt itself (see Blanchard 2004; Taghizadeh-hesary 2018). Lastly, we find that the central bank's independence and unemployment rate weakly affect the inflation rates.

Table 3. Estimation Results of the Second Model Estimate

\begin{tabular}{|c|c|c|c|c|}
\hline & (1) & (2) & (3) & (4) \\
\hline \multirow{2}{*}{ Credibility (-1) } & $0.5055088 * * *$ & $0.4680264 * * *$ & $0.4792005 * * *$ & $0.3921223 * * *$ \\
\hline & $(0.149375)$ & $(0.1444329)$ & $(0.1419244)$ & $(0.1434911)$ \\
\hline \multirow{2}{*}{ Fiscal Cyclicality } & 0.0380928 & 0.0232488 & 0.0229106 & 0.0251048 \\
\hline & $(0.0329892)$ & $(0.0297133)$ & $(0.0297916)$ & $(0.0235891)$ \\
\hline \multirow{2}{*}{ Debt to GDP Ratio } & & 0.0003599 & 0.0003775 & 0.0004697 \\
\hline & & $(0.0002541)$ & $(0.0002598)$ & $(0.000342)$ \\
\hline Central & & & $0.0522614 * * *$ & $0.0547082 * * *$ \\
\hline Independence & & & $(0.0154084)$ & $(0.0078552)$ \\
\hline Central & & & & $-0.0076015^{*}$ \\
\hline Transparency & & & & $(0.0040882)$ \\
\hline $\begin{array}{l}\text { Overidentification } \\
\text { (Hansen J-test) }\end{array}$ & 18.19 & 13.64 & 13.62 & 12.82 \\
\hline AR (2) Test & 0.74 & 0.68 & 0.70 & 0.64 \\
\hline Wald Statistics & $12.39 * * *$ & $10.87 * * *$ & $16.55 * * *$ & $104.12 * * *$ \\
\hline Instrumental Variables & 17 & 17 & 17 & 17 \\
\hline Number of Observation & 325 & 325 & 325 & 325 \\
\hline Number of Countries & 25 & 25 & 25 & 25 \\
\hline Estimator & Differenced GMM & Differenced GMM & Differenced GMM & Differenced GMM \\
\hline
\end{tabular}

Notes: The asterisk denotes statistical significance *, **, and *** at 10 percent, 5 percent, and 1 percent, respectively.

Numbers in the parentheses ( ) represent robust standard error.

We proceed with the investigation on the empirical evidence which is accommodated in the second model estimate estimation (see table 3). Firstly, for the specification tests of the model estimate, our results show that the estimations are also valid in terms of the validity of the IV and no autocorrelation. The estimated Chi-squared for the Hansen J-test is insignificant for all estimations, implying the validity of the set of IV. For the AR autocorrelation, all estimations are not distorted by serial correlation, reflected by the insignificant $\mathrm{Z}$-stat for the second-order error terms.

For the estimation results, we find that the empirical relationship between cyclicality behavior of fiscal policy and the credibility of monetary is consistently insignificant in various ways of model specification. This confirms our conjecture that stated fiscal cyclicality would not affect monetary policy credibility since the monetary authority would directly respond to the potential distortion derived from procyclical fiscal policy circumstances. The monetary authority obviously would strive to hold its credibility by employing both a negative money growth policy and significantly increases interest rates; therefore, it would be precisely re-arrayed the targeted, expected, and actual inflation rates at the same level. Eventually, the monetary authority could assure its credibility, although the fiscal policy is procyclical. This finding is also consistent with the previous literature, which addressed that monetary policy would hold its credibility by operating a consistent policy rule to achieve the policy objective (e.g., see Barro and Gordon 1983; Kydland and Prescott 1977; Fellner 1979; Mccallum 1984). For the control variables, we find the following findings. On public debt, we find weak evidence on the consequences of the public debt size towards monetary policy credibility. For the central bank independence, our finding suggests that the less independent the central bank the more credible the monetary policy. For central bank transparency, we find weak evidence for the empirical relationship between central bank transparency and monetary policy credibility.

\subsection{Robustness Checks}

The first strategy to afford robust findings and rationalizations is that we are not only employing a rolling correlation for cyclicality behavior of fiscal policy measurement but also rolling regression in a 20 -years window. In this field, the regression approach is frequently utilized in numerous works of literature (e.g., Gavin and Perotti 1997; Tornell and Lane 1999; Kaminsky, Reinhart, and Végh 2004; Mackiewicz 2008; Park 2012; J. A. Frankel, Vegh, and Vuletin 2013; Mcmanus and Ozkan 2015; and Alesina and Tabelli 2016). Specifically, we regress the cyclicality behavior of fiscal policy for each country separately as the following equation:

$$
\tau_{t}^{\Delta}=\alpha_{t}+\beta y_{t}^{\Delta}+\varepsilon_{t}
$$

Where $\tau_{t}^{\Delta}, y_{t}^{\Delta}, \alpha_{t}, \beta$ and $\varepsilon_{t}$ are the first-differenced of government expenditure, the first-differenced of real GDP, 
fiscal cyclicality behavior parameter, constant, and error term for each point of time $t$, respectively.

Furthermore, to ensure a robust measurement for monetary credibility, we also utilize the inflation expectation volatility in this concern. Theoretically, Rogoff's (1985) seminal paper has revealed that with the more committed (credible) central bank to fight the inflation thus its volatility would be diminished, although at the expense of growth volatility. While in the empirical fields, this approach has been frequently used in several works of the literature (e.g., Adler, Lama, and Medina 2019). This paper thus identifies explicitly the degree of monetary policy credibility as the monthly-annualized standard deviation of the expected inflation rate which is estimated using the Hodrick-Prescott smoothed trend.

Table 4. Robustness Check Estimations

\begin{tabular}{|c|c|c|c|c|c|c|}
\hline & $(1)$ & (2) & (3) & (4) & (5) & (6) \\
\hline Inflation $(-1)$ & $\begin{array}{c}0.1554177 \\
(0.1994863)\end{array}$ & $\begin{array}{c}0.398986 * * \\
* \\
(0.0728197)\end{array}$ & $\begin{array}{c}0.7913306 * * * \\
(0.2630852)\end{array}$ & & & \\
\hline Credibility (-1) & & & & $\begin{array}{c}1.220807 * * * \\
(0.4150111)\end{array}$ & $\begin{array}{r}1.67794 * * * \\
(0.2516694)\end{array}$ & $\begin{array}{c}0.7795599 * * * \\
(0.2969559)\end{array}$ \\
\hline $\begin{array}{l}\text { Fiscal } \\
\text { Cyclicality }\end{array}$ & $\begin{array}{c}0.0572148 \\
(0.0512847)\end{array}$ & $\begin{array}{c}0.0119095 \\
(0.0123289)\end{array}$ & $\begin{array}{c}0.0259122 * * \\
(0.0109696)\end{array}$ & $\begin{array}{c}0.0047724 \\
(0.0057738)\end{array}$ & $\begin{array}{c}-0.0018703 \\
(0.0041043)\end{array}$ & $\begin{array}{c}0.0090332 \\
(0.0081733)\end{array}$ \\
\hline $\begin{array}{l}\text { Broad Money } \\
\text { Growth }\end{array}$ & $\begin{array}{c}0.0004061 \\
(0.0002673)\end{array}$ & $\begin{array}{c}0.001086^{* *} \\
* \\
(0.0003034)\end{array}$ & $\begin{array}{c}0.0008478 * * * \\
(0.0002577)\end{array}$ & & & \\
\hline $\begin{array}{l}\text { Unemployment } \\
\text { Rate }\end{array}$ & $\begin{array}{c}-0.1719866 \\
(0.273453)\end{array}$ & $\begin{array}{l}-0.0189458 \\
(0.0614006)\end{array}$ & $\begin{array}{l}-0.1782421 \\
(0.1310467)\end{array}$ & & & \\
\hline $\begin{array}{l}\text { Debt to GDP } \\
\text { Ratio }\end{array}$ & $\begin{array}{l}-0.0000723 \\
(0.000376)\end{array}$ & $\begin{array}{c}-0.0000708 * \\
* \\
(0.000035)\end{array}$ & $\begin{array}{l}0.0001995^{*} \\
(0.0001141)\end{array}$ & $\begin{array}{c}0.0002139 \\
(0.0001469)\end{array}$ & $\begin{array}{c}0.0000176 \\
(0.0000198)\end{array}$ & $\begin{array}{c}0.0001149 * * \\
(0.0000496)\end{array}$ \\
\hline $\begin{array}{l}\text { Central Bank } \\
\text { Independence } \\
\text { Central Bank } \\
\text { Transparency }\end{array}$ & $\begin{array}{l}0.029479 * * \\
(0.0137476)\end{array}$ & $\begin{array}{c}0.0062841 \\
(0.01317)\end{array}$ & $\begin{array}{l}-0.0207355 \\
(0.0372799)\end{array}$ & $\begin{array}{c}0.0011988 \\
(0.0032968) \\
-0.002837 * \\
(0.0016881)\end{array}$ & $\begin{array}{l}-0.0162758 \\
(0.0116121) \\
-0.0003069 \\
(0.0004482)\end{array}$ & $\begin{array}{c}0.0058059 \\
(0.0065946) \\
-0.0027352 * * \\
(0.0012323)\end{array}$ \\
\hline Constant & & $\begin{array}{c}0.0112857 \\
(0.0107914) \\
\end{array}$ & & & $\begin{array}{r}0.0087902 \\
(0.0081724) \\
\end{array}$ & \\
\hline $\begin{array}{l}\text { Overidentificati } \\
\text { on Test (Hansen } \\
\text { J-test) }\end{array}$ & $20.21 *$ & 18.52 & exactly identified & 18.24 & 15.18 & exactly identified \\
\hline AR (2) Test & 0.32 & 0.61 & & -0.24 & -1.27 & \\
\hline $\begin{array}{l}\text { Kleibergen-Paa } \\
\text { p rk LM statistic }\end{array}$ & & & $18.079 * * *$ & & & $7.881 * * *$ \\
\hline $\begin{array}{l}\text { Wald Statistics } \\
\text { R-squared }\end{array}$ & $29.75 * * *$ & $173.00 * * *$ & 0.3122 & 16.42 & 91.1 & 0.5944 \\
\hline $\begin{array}{l}\text { Instrumental } \\
\text { Variables }\end{array}$ & 18 & 20 & & 17 & 19 & \\
\hline $\begin{array}{l}\text { Number } \\
\text { Observation }\end{array}$ & 312 & 338 & 313 & 312 & 336 & 312 \\
\hline $\begin{array}{l}\text { Number } \\
\text { Countries }\end{array}$ & 25 & 25 & 25 & 24 & 24 & 25 \\
\hline Estimator & $\begin{array}{l}\text { Differenced } \\
\text { GMM } \\
\end{array}$ & $\begin{array}{l}\text { System } \\
\text { GMM }\end{array}$ & $\begin{array}{l}\text { Fixed-Effect } \\
\text { IV-2SLS }\end{array}$ & $\begin{array}{c}\text { Differenced } \\
\text { GMM }\end{array}$ & $\begin{array}{l}\text { System } \\
\text { GMM }\end{array}$ & $\begin{array}{l}\text { Fixed-Effect } \\
\text { IV-2SLS }\end{array}$ \\
\hline
\end{tabular}

Notes: The asterisk denotes statistical significance *, **, and *** at 10 percent, 5 percent, and 1 percent, respectively. Numbers in the parentheses ( ) represent robust standard error.

Table 4 depicts the estimation results for the robustness checks. For the estimator, we use three approaches, i.e., differenced GMM, system GMM, dan fixed-effect 2SLS model. Our estimations suggest that the coefficients of cyclicality behavior of fiscal policy are consistently generating positive value in various estimation methods and it is significant using Fixed-Effect IV 2SLS. This finding is consistent with the main estimation (Table 2), indicating that procyclical fiscal policy generates higher inflation. On the other hand, the second model estimate demonstrates the evidence that fiscal cyclicality inadequately affects the credibility of monetary policy in various estimators. Based on these estimations, therefore, it indicates that our findings are robust concerning various ways of estimation and variable measurement. 


\subsection{Discussions}

In the first stage of empirical investigation, we find that if the fiscal policy tended to behave procyclically would cause increases in the inflation rate which is well-matched to Mcmanus and Ozkan's (2015) findings. As Kaminsky, Reinhart, and Végh (2004) have revealed, the procyclical fiscal policy could affect the inflation rates by "turning sunny days into scorching infernos": procyclically expansions in government expenditure would excessively boost the aggregate demand, set the economy into the "over-heated" circumstances, therefore inevitably soaring the inflation rates.

Table 5. Summary of Main Findings

\begin{tabular}{cccc}
\hline Dependent Variables & Independent Variable & $\begin{array}{c}\text { Research } \\
\text { Hypothesis }\end{array}$ & Empirical Findings \\
\hline Inflation Rate & Cyclicality Behavior of Fiscal & + & Positive (Significant) \\
The Credibility of Monetary Policy & Policy & 0 & Positive (Insignificant) \\
\hline
\end{tabular}

On the second empirical scrutiny, we find that our empirical findings are also consistent with the hypothesis. Since the monetary authority would directly respond to the potential distortion derived from procyclical fiscal policy circumstances, the monetary authority obviously would strive to keep its credibility by employing both a negative money growth policy and significantly increases interest rates. Therefore, the monetary authority could assure its credibility by re-arraying the targeted, expected, and actual inflation rates at the same level. This finding is also consistent with the previous literature, which addressed that monetary policy would hold its credibility by operating a consistent policy rule to achieve the policy objective (e.g., see Barro and Gordon 1983; Kydland and Prescott 1977; Fellner 1979; Mccallum 1984).

Nonetheless, the questions in mind are whether the credibility of monetary policy is not under pressure and has no consequences for the economy when the procyclical fiscal policy does exist. The procyclical fiscal policy would initially deteriorate the credibility of monetary policy by generating a gap between targeted, actual, and expected inflation rates. Afterward, the monetary authority would attempt to keep its credibility by employing a negative money growth policy, which also significantly increases interest rates, to adjust the deviation between targeted, expected, and actual inflation rates (see proposition 4). Therefore, it restraints domestic investment and slows down economic growth. On the other hand, in the persistence of financial bubbles, a significant increase in interest rate implies: higher borrowing costs, reduce leverage, increase financial risk, consequently exacerbating financial stability (Dell'Ariccia, Laeven, and Marquez 2014; Fouejieu, Popescu, and Villieu 2019). Finally, a credible monetary policy is possibly obtained by deteriorating economic growth and financial stability (Kurnia et al. 2020).

In contrast, if the fiscal policy is countercyclical, there are no reasons for the monetary authority to raise interest rates surprisingly or, at least, step by step. Furthermore, the countercyclical fiscal policy could restraint excessive booms and busts of business cycles, then reduce the procyclicality of the financial sector, thus not only keeping financial stability in order but also promoting the lower forgone output cost.

\subsection{Policy Implications}

Although this paper illustrates no consequences of cyclicality behavior of fiscal policy on the credibility of monetary policy, the procyclical fiscal policy could potentially exacerbate the outcomes of monetary credibility.

A growing literature has demonstrated that the procyclicality of fiscal policy is mainly driven by the institutional and political economy aspects. Tornell and Lane (1999) revealed that the higher degree of concentration of political power (i.e., low degree of democracy) decelerates economic growth and a higher degree of procyclicality of fiscal policy in response to the economic cyclical. Also, output volatility is one of the reasons that explain fiscal policy is often procyclical. Ilzetzki (2011) also found that political distortion in fiscal policy could explain the cyclicality behavior of fiscal policy - the magnitude of political distortion causes the fiscal policy to be procyclical. Alesina and Tabelli (2016) revealed that when voters consider the government to be Leviathan, they will encourage demand for public goods and request a reduction in tax rates when there is a boom to avoid political rent. On the other hand, however, this encourages a procyclical bias in fiscal policy. Therefore, procyclical fiscal policies occur in countries with corrupt governments.

Gavin and Perotti (1997), one of the pioneers in discussing the cyclicality behavior of fiscal policy, also explained that the limitations in accessing international loans (borrowing constraints) are factors that can determine the procyclicality behavior of fiscal policies. Kaminsky, Reinhart, and Végh (2004) find the same thing, where fiscal policy in the majority of developing countries is procyclical and is accompanied by cyclicality behavior of procyclical foreign capital flows. Besides, the period in which capital inflows are associated with an expansionary macroeconomic policy, vice versa. 
Based on these works of literature, we provide several policy implications. One effort that could be done to reduce political distortion and institutional problems (corruption) is to establish an Independent Fiscal Policy Implementation Supervisory Agency (IFPISA). With IFPISA, fiscal policy implementation could be monitored objectively and can reduce political distortion. Besides, of course, a mechanism for preventing and enforcing corruption is integrated with all elements of the institution to reduce the corrupt behavior of public officials (Pope 2000). The central bank also could anticipate this situation with Capital Flow Management (CFM) and increase the depth of the domestic financial sector (financial deepening). Through CFM, the central bank can regulate incentives for foreign capital inflows to avoid excessive inflows or outflows from both domestic and international economic actors by taking into account domestic and global business cycles. Meanwhile, with a more profound financial sector, the economy has a more significant source of domestic funding and can minimize the consequences of capital outflows-Furthermore, the problem of borrowing constraints faced by the government to carry out countercyclical fiscal policies.

\section{Concluding Remarks}

If indiscipline fiscal policy could distort the objective and the effectiveness of the monetary policy, is it necessarily mean that procyclical fiscal policy deteriorates monetary policy credibility? This paper addresses the issue by examining the consequences of procyclical fiscal policy on the credibility of monetary policy. We perform two stages of empirical investigation by which are articulated into two model estimates. Firstly, we explore the empirical relationship between inflation rates, as the objective of monetary policy, and cyclicality behavior of fiscal policy. Afterward, we proceed with the investigation on the impact of fiscal policy cyclicality behavior directly towards monetary policy credibility. This paper also employs several robustness tests to ensure the empirical findings are robust.

Our empirical investigations robustly find that the procyclical fiscal policy significantly exacerbates the inflation rate. Procyclical fiscal policy excessively pushes the aggregate demand, over-heating the economy, therefore exacerbating inflation rates. Second, we robustly find that the empirical relationship between cyclicality behavior of fiscal policy and the credibility of monetary is statistically insignificant, which implies that procyclical fiscal policy would not deteriorate the credibility of monetary policy. Since the monetary authority would directly respond to the potential distortion derived from procyclical fiscal policy circumstances, the monetary authority obviously would strive to keep its credibility by employing tighter monetary policy.

\section{The Statement of Authorship}

Conceptualization, S.I. and A.S.K.; Literature Review, S.I. and A.S.K.; Methodology, S.I. and A.S.K.; Software, S.I..; Validation, S.I. and A.S.K.; Formal analysis, S.I. and A.S.K.; Investigation, S.I. and A.S.K.; Writing original draft preparation, S.I. and A.S.K.; writing review and editing, S.I. and A.S.K.; All authors have read and agreed to the published version of the manuscript.

\section{Acknowledgment}

Firstly, we want to thank FX. Sugianto and. Maruto Umar Basuki by giving us priceless discussions to construct this paper. We also want to thank Arief Anshory Yusuf (Padjajaran University, Indonesia) and Matteo Lanzafame (Asian Development Bank Institute) for the essential review at the $13^{\text {th }}$ BMEB International Conference and Call for Paper, Bank Indonesia. Lastly, we would like to thank the Bank Indonesia Institute for providing a research fund for this paper through Bank Indonesia’s Student Research Grant Program 2019.

\section{Funding}

This paper is funded by Bank Indonesia’s Student Research Grant Program 2019.

\section{Conflict of Interest}

The funding institution had no role in the design of the study, in the collection, analyses, or interpretation of data, in the writing of the manuscript, and in the decision to publish the results.

\section{Data Availability Statement}

The data employed in this paper are publicly available on Bank for International Settlements, International Financial Statistics (IMF), Penn World Table (available for download at www.ggdc.net/pwt), Historical Public Finance Dataset (IMF), and World Economic Outlook (IMF). We provide our dataset when demanded.

\section{References}

Adler, G., Ruy, L., \& Juan, P. M. (2019). Foreign Exchange Intervention and Inflation Targeting: The Role of Credibility. Journal of Economic Dynamics and Control, 106, 103716. https://doi.org/10.1016/j.jedc.2019.07.002

Alberola, E., \& Jose, M. M. (2011). Debt Sustainability and Procyclical Fiscal Policies in Latin America. SSRN Electronic Journal. https://doi.org/10.2139/ssrn.903066 
Alesina, A., \& Roberta, G. (1995). Independent Central Banks: Low Inflation at No Cost? The American Economic Review, 85(2), 196-200. Retrieved from http://www.jstor.org/stable/2117918

Alesina, A., \& Tabelli. (2016). Why Is Fiscal Policy Often Procyclical? Journal of the European Economic Association, 6(5), 1006-36. https://doi.org/10.1162/JEEA.2008.6.5.1006

Alisa, M. (2015). The Relationship between Inflation and Unemployment: A Theoretical Discussion about the Philips Curve. Journal of International Business and Economics, 3(2), 89-97. https://doi.org/10.15640/jibe.v3n2a7

Arellano, M., \& Stephen, B. (1991). Some Tests of Specification for Panel Carlo Application to Data. Review of Economic Studies, 58, 277-97. https://doi.org/10.2307/2297968

Bakas, D., \& Georgios, C. (2019). Inflation Dynamics and the Output-Inflation Trade-Off: International Panel Data Evidence. Economic Inquiry. https://doi.org/10.1111/ecin.12798

Baltagi, B. H. (2005). Econometric Analysis of Panel Data (3rd ed.). West Sussex PO19 8SQ, England: John Wiley \& Sons Ltd.

Barro, R. J., \& David, B. G. (1983). Rules, Discretion and Reputation In a Model of Monetary Policy. NBER Working Paper Series, 1079, 364-88. https://doi.org/10.3386/w1079

Bianchi, F., \& Cosmin, I. (2017). Monetary/Fiscal Policy Mix and Agents' Beliefs. Review of Economic Dynamics, 26, 113-39. https://doi.org/10.1016/j.red.2017.02.011

Bjørnstad, R., \& Ragnar, N. (2008). The New Keynesian Phillips Curve Tested on OECD Panel Data. Economics: The Open-Access, Open-Assessment E-Journal, 2(23), 1. https://doi.org/10.5018/economics-ejournal.ja.2008-23

Blanchard, O. J. (2004). Fiscal Dominance and Inflation Targeting: Lessons from Brazil. Ssrn. https://doi.org/10.2139/ssrn.518265

Blinder, A. S. (2000). Central-Bank Credibility: Why Do We Care? How Do We Build It? American Economic Review, 90(5), 1421-31. https://doi.org/10.1257/aer.90.5.1421

Boiciuc, I. (2015). The Cyclical Behavior of Fiscal Policy in Romania. Procedia Economics and Finance, 32(15), 286-91. https://doi.org/10.1016/s2212-5671(15)01393-3

Bond, S. (2002). Dynamic Panel Data Models: A Guide to Micro Data Methods and Practice. CWP09/02. Cemmap Working Paper Series. London. https://doi.org/10.1007/s10258-002-0009-9

Camous, A., \& Andrew, R. G. (2018). Public Debt and Fiscal Policy Traps. Journal of Economic Dynamics and Control 93, 239-59. https://doi.org/10.1016/j.jedc.2018.02.009

Chadha, J. S., \& Charles, N. (2003). On the Interaction of Monetary and Fiscal Policy. Dynamic Macroeconomic Analysis, 0303, 243-307. https://doi.org/10.1017/9781139165235.007

Correia, I., João, C. N., \& Sergio, R. (1995). Business Cycles in a Small Open Economy. European Economic Review, 39(6), 1089-1113. https://doi.org/10.1016/0014-2921(94)00105-9.

Cottarelli, C. (1998). The Nonmonetary Determinants of Inflation: A Panel Data Study. IMF Working Papers. https://doi.org/10.5089/9781451844016.001

Cukierman, A. (1986). Central Bank Behavior and Credibility: Some Recent Theoretical Developments. Review, 68, https://doi.org/10.20955/r.68.5-17.him

Dell'Ariccia, G., Luc, L., \& Robert, M. (2014). Real Interest Rates, Leverage, and Bank Risk-Taking. Journal of Economic Theory, 149(1), 65-99. https://doi.org/10.1016/j.jet.2013.06.002

Deniz, P., Mahmut, T., \& Ahmet, Y. (2016). Investigating the Determinants of Inflation: A Panel Data Analysis. International Journal of Financial Research, 7(2), 233-46. https://doi.org/10.5430/ijfr.v7n2p233

Dincer, N., \& Barry, E. (2015). Central Bank Transparency and Independence: Updates and New Measures. SSRN Electronic Journal, no. December 2011. https://doi.org/10.2139/ssrn.2579544

Elbadawi, I., Mohamed, G., \& Moez, B. T. (2017). Fiscal-Monetary Interdependence and Exchange Rate Regimes in Oil-Dependent Arab Economies. 1116. 21 Al-Sad Al-Aaly Street Dokki, Giza Egypt.

Fellner, W. (1979). The Credibility of Effect and Rational Expectations: Implications of the Gramlich Study. Brookings Paper Economic Act., 1, 167-89. https://doi.org/10.2307/2534307

Ferreira, A., Elano, M. T. A. O. de Olivindo, \& Ivan, C. (2018). Business Cycles, Expectations and Inflation in Brazil: A New-Keynesian Phillips Curve Analysis. CEPAL Review, 124, 143-58. https://doi.org/10.18356/295f47b6-en

Fouejieu, A., Alexandra, P., \& Patrick, V. (2019). Trade-Offs between Macroeconomic and Financial Stability 
Objectives. Economic Modelling, 81, 621-39. https://doi.org/10.1016/j.econmod.2019.02.006

Frankel, J. (2010). Monetary Policy in Emerging Markets. Handbook of Monetary Economics, 3(C), 1439-1520. https://doi.org/10.1016/B978-0-444-53454-5.00013-X

Frankel, J. A., Carlos, A. V., \& Guillermo, V. (2013). On Graduation from Fiscal Procyclicality. Journal of Development Economics, 100(1), 32-47. https://doi.org/10.1016/j.jdeveco.2012.07.001

Friedman, M. (1968). The Role of Monetary Policy. The American Economic Review, LVIII(March), 1-17. https://doi.org/10.1126/science.151.3712.867-a

Fritsche, U., Jiri, S., \& Jonas, D. (2009). Disagreement Among Forecaster in G7 Countries. 94 (November), 1081-96. https://doi.org/10.1162/REST_a_00207

Garriga, A. C. (2016). Central Bank Independence in the World: A New Data Set. International Interactions, 42(5), 849-68. https://doi.org/10.1080/03050629.2016.1188813

Gavin, M., \& Roberto, P. (1997). Fiscal Policy in Latin America. In NBER Macoeconomics Annual, 12, 11-61. https://doi.org/10.1093/oxfordhb/9780199571048.013.0011

Hammond, G. (2012). State of the Art Inflation Targeting. 29. CCBS Handbook No. 29 - February 2012 Version. CCBS Handbook. Threadneedle Street, London, EC2R 8AH.

Hong, G. H., Rahul, A., \& Yaroslav, H. (2019). Achieving the Bank of Japan's Inflation Target. IMF Working Papers, 19(229). https://doi.org/10.5089/9781513518350.001.

Ilzetzki, E. (2011). Rent-Seeking Distortions and Fiscal Procyclicality. Journal of Development Economics, 96(1), 30-46. https://doi.org/10.1016/j.jdeveco.2010.07.006

Kabundi, A, \& Montfort, M. (2019). The Role of Monetary Policy Credibility in Explaining the Decline in Exchange Rate Pass-through in South Africa. Economic Modelling, 79(173), 173-85. https://doi.org/10.1016/j.econmod.2018.10.010

Kabundi, A., \& Mlachila, M. M. (2018). Monetary Policy Credibility and Exchange Rate Pass-Through in South Africa. WP/18/173. IMF Working Paper. https://doi.org/10.5089/9781484371671.001

Kaminsky, G. L., Carmen, M. R., \& Carlos, A. V. (2004). When It Rains, It Pours: Procyclical Capital Flows and Macroeconomic Policies. 10780. NBER Working Paper Series. 1050 Massachusetts Avenue, Cambridge, MA 02138. https://doi.org/10.3386/w10780

Kim, D. H., Shu, C. L., \& Yi, C. W. (2014). Globalization and Inflation: New Panel Evidence. Macroeconomic Dynamics, 20(1), 1-26. https://doi.org/10.1017/S1365100514000510

Kurnia, A. S., Syahid, I., Johan, B. M., \& Agung, K. (2020). Inflation and Financial Stability Trade-off: Role of Monetary Policy Credibility and Fiscal Cyclicality. Economic Papers, 1-19. https://doi.org/10.1111/1759-3441.12297

Kydland, F. E., \& Edward, C. P. (1977). Rules Rather than Discretion: The Inconsistency of Optimal Plans. Journal of Political Economy, 85(3), 473-91. https://doi.org/10.1086/260580

Leeper, E. M., \& Leith, C. (2016). Understanding Inflation as a Joint Monetary-Fiscal Phenomenon. Handbook of Macroeconomics. 1st ed. Vol. 2. Elsevier B.V. https://doi.org/10.1016/bs.hesmac.2016.03.012

Mackiewicz-Łyziak, J. (2016). Central Bank Credibility: Determinants and Measurement. A Cross-Country Study. Acta Oeconomica, 66(1), 125-51. https://doi.org/10.1556/032.2016.66.1.6

Mackiewicz, M. (2008). Determinants of Cyclicality of Fiscal Surpluses in The OECD Countries. MPRA Paper, no. 16034. https://doi.org/10.3109/15368378209040332

Mccallum, B. T. (1984). Credibility and Monetary Policy. 1490. NBER Working Paper Series. 1050 Massachusetts Avenue Cambridge. https://doi.org/10.3386/w1490

Mcmanus, R., \& F. Gulcin, O. (2015). On the Consequences of Procyclical Fiscal Policy. Fiscal Studies, 36(1), 29-50. https://doi.org/10.1111/j.1475-5890.2015.12044.x

Moreira, R. R. (2012). Interest Rate Shocks, Central Bank's Credibility and Inflation Targeting Regime: Simulations in a Dynamic Stochastic General Equilibrium Model. Procedia Economics and Finance, 1(12), 286-95. https://doi.org/10.1016/s2212-5671(12)00033-0

Park, J. (2012). Determinants and Consequences of Fiscal Procyclicality and Sustainability, no. July. http://etheses.whiterose.ac.uk/3120/ 
Persson, T., \& Guido, T. (1999). Political Economics and Macroeconomic Policy. In Handbook of Macroeconomics, 1, 1397-1482. https://doi.org/10.1016/S1574-0048(99)10035-1

Pope, J. (2000). Confronting Corruption: The Elements of a National Integrity System. 1st THUS e. Transparency International.

Robert, M. (2014). Central Banking: Perspectives from Emerging Economies. 2014-006. La Follette School Working Paper Series. 1225 Observatory Drive, Madison, Wisconsin 53706.

Rogoff, K. (1985). The Optimal Degree of Commitment to an Intermediate Monetary Target Author ( s ): Kenneth Rogoff Source. The Quarterly Journal of Economics , 100(4), 1169-1189. https://doi.org/10.2307/1885679

Roodman, D. (2009). How to Do Xtabond2: An Introduction to Difference and System GMM in Stata. Stata Journal, 9(1), 86-136. https://doi.org/10.1177/1536867x0900900106

Sargent, T. J., \& Neil, W. (1981). Some Unpleasant Monetarist Arithmetic. Federal Reserve Bank of Minneapolis Quarterly Review, 5(3), 1-17. https://doi.org/10.21034/qr.531

Sidrauski, M. (1967). Inflation and Economic Growth. Journal of Political Economy, 75(6), 796-810. https://doi.org/dx.doi.org/10.1086/259360

Taghizadeh-hesary, F. (2018). Fiscal Policy Conditions For Government Budget Stability And Economic Recovery: Comparative Analysis Of Japan And Greece." 851. ADBI Working Paper Series.

Talvi, E., \& Carlos, A. V. (2005). Tax Base Variability and Procyclical Fiscal Policy in Developing Countries. Journal of Development Economics, 78(1), 156-90. https://doi.org/10.1016/j.jdeveco.2004.07.002

Tornell, A., \& Philip, R. L. (1999). The Voracity Effect. Journal of Economic Perspectives, 89(1), 22-46. https://doi.org/10.1257/aer.89.1.22

Vegh, C. A., \& Guillermo, V. (2012). Overcoming the Fear of Free Falling: Monetary Policy Graduation in Emerging Markets. NBER WORKING PAPER SERIES, 18175, 105-29. https://doi.org/10.1142/9789814449922_0006

Warjiyo, P., \& Solikin, M. J. (2019). Central Bank Policy: Theory and Practice. First. Wagon Lane, Bingley BD161WA, UK: Emerald Publishing Limited. https://doi.org/10.1108/9781789737516

Woo, J. (2009). Why Do More Polarized Countries Run More Procyclical Fiscal Policy? Review of Economics and Statistics, 91(4), 850-70. https://doi.org/10.1162/rest.91.4.850

Woodford, M. (1995). Price Level Determinacy Without Control of a Monetary Aggregate. 5204. NBER Working Paper Series. 1050 Massachusetts Avenue, Cambridge, MA 02138. https://doi.org/10.3386/w5204

Zeng, N. (2018). Inflation Persistence and Monetary Policy Credibility: A Revisit of the Credibility Hypothesis. American Journal of Economics, 8(3), 138-45. https://doi.org/10.5923/j.economics.20180803.03 


\section{Appendix A. Variables and Data Source}

\begin{tabular}{|c|c|c|c|}
\hline Variables & Technical Description & Measurement/Unit of Account & Data Source \\
\hline $\begin{array}{l}\text { The Credibility of } \\
\text { Monetary Policy }\end{array}$ & $\begin{array}{l}\text { Smoothed value of absolute deviation } \\
\text { between actual and expected inflation. }\end{array}$ & $\begin{array}{c}C M P=\frac{\left|\pi-\pi^{e}\right|}{\left(1+\left|\pi-\pi^{e}\right|\right)} \times 100 ; \\
\text { Where } C M P \geq 0\end{array}$ & $\begin{array}{l}\text { Author's } \\
\text { calculation, Bank } \\
\text { for International } \\
\text { Settlement }\end{array}$ \\
\hline $\begin{array}{l}\text { Cyclicality Behavior of } \\
\text { Fiscal Policy }\end{array}$ & $\begin{array}{l}\text { Correlation between the first-differenced } \\
\text { government expenditure and the output } \\
\text { gap. }\end{array}$ & $\begin{array}{l}\text { The rolling correlation coefficient } \\
\qquad(20 \text { years window) }\end{array}$ & $\begin{array}{l}\text { World Bank Data, } \\
\text { IMF Public } \\
\text { Finance Historical } \\
\text { Dataset }\end{array}$ \\
\hline Inflation Rates & The annual growth rate of CPI. & $\begin{array}{c}\text { Percentage } \\
(2010=100)\end{array}$ & $\begin{array}{c}\text { World Economic } \\
\text { Outlook, IMF. } \\
\text { International } \\
\text { Financial } \\
\text { Statistics, and BIS. }\end{array}$ \\
\hline Public Debt & General government gross debt. & Percentage of GDP & World Bank Data \\
\hline Unemployment Rate & Unemployment to labor force ratio. & Percentage & $\begin{array}{l}\text { World Economic } \\
\text { Outlook, IMF }\end{array}$ \\
\hline Exchange Rates & $\begin{array}{l}\text { CPI-based real effective exchange rates } \\
\qquad \text { (REER). }\end{array}$ & Index & $\begin{array}{c}\text { International } \\
\text { Financial Statistics } \\
\text { and FRED }\end{array}$ \\
\hline $\begin{array}{c}\text { Growth Rate of Broad } \\
\text { Money }\end{array}$ & $\mathrm{M}_{2}$ growth rate. & Percentage & World Bank Data \\
\hline $\begin{array}{c}\text { Central Bank } \\
\text { Independence Index (CBI) }\end{array}$ & $\begin{array}{l}\text { The central bank's freedom is based on } \\
\text { laws that are free from political } \\
\text { considerations and interference from } \\
\text { other parties (Warjiyo and Juhro 2019). }\end{array}$ & $\begin{array}{l}\text { Indexed de jure } \\
\text { measurement } \\
\text { (score: } 0-1 \text { ) }\end{array}$ & Garriga (2016) \\
\hline $\begin{array}{c}\text { Central Bank Transparency } \\
\text { Index (CBT) }\end{array}$ & $\begin{array}{l}\text { Precisely conveying accurate } \\
\text { information to form opinions on } \\
\text { monetary policy (Poole 2003). }\end{array}$ & $\begin{array}{l}\text { Indexed de facto measurement } \\
\text { (score: } 0-15)\end{array}$ & $\begin{array}{c}\text { Dincer and } \\
\text { Eichengreen } \\
\text { (2015) }\end{array}$ \\
\hline
\end{tabular}

\section{Copyrights}

Copyright for this article is retained by the author(s), with first publication rights granted to the journal.

This is an open-access article distributed under the terms and conditions of the Creative Commons Attribution license which permits unrestricted use, distribution, and reproduction in any medium, provided the original work is properly cited. 